\title{
Preparation and test of sprayable gypsum-based mortar
}

\author{
XiaoLiang Luo ${ }^{1, a}$, KaiSheng $\mathrm{Wu}^{2, b}$ \\ ${ }^{1}$ Chongqing Technology and Business Institute, Chongqing, 401520, China \\ 2 Jiangsu nigao Science and Technology Ltd.,jiang su, 213015, China \\ a23991016@qq.com, bkevinlsl520@126.com
}

Keywords: desulphurized gypsum, gypsum mortar, spray, constructability

Abstract. Sprayable gypsum-based mortar was prepared by using desulphurized gypsum as cementitious material. Through the test, this study analyzed the influences of lightweight aggregate, water retention agent and thixotropic agent on compression strength, tensile bond strength, water retention rate and constructability of sprayable gypsum-based mortar. Based on this, the mixture ratio of sprayable gypsum-based mortar was determined and applied in practical engineering.

\section{Introduction}

In China, large quantities of industrial by-product gypsum are produced every year, but the comprehensive utilization rate is low. Moreover, mass accumulations of gypsum not only occupy the land and pollute the environment but also waste resources [1]. At present, many researchers have conducted lots of researches on properties of desulphurized gypsum and issues related to calcining process. These studies show that desulphurized gypsum has good cementitious property and is similar to natural dihydrate gypsum in physical property, chemical property and mineral components. This provides a basis for comprehensively utilizing desulphurized gypsum [2]. Producing plastering gypsum with desulphurized gypsum solves the accumulation problem of desulphurized gypsum, thus effectively utilizing desulphurized gypsum resources. Furthermore, owing to plastering gypsum has light weight and micro-expansion nature and can be solidly bonded with the base, the common quality problems, like hollowing, fracturing and spalling in plaster engineering are solved [3]. However, plastering gypsum prepared with desulphurized gypsum shows large viscosity and calls for toilsome work in construction, so it is faced with great difficulties in large-scale popularization and application. In Europe, gypsum-based mortar has occupied more than $90 \%$ markets of wall materials for industrial and household decoration.

Gypsum-based mortar for mechanical spraying construction not only needs to meet the technical requirements of the relevant standards and specifications but also requires having pump transmission and spraying property. In other words, it has to show good theology, workability and wet adhesion and appropriate particle composition and setting time. By referring to existing scientific research achievements, raw materials were selected to conduct the test[4]. Moreover, this study analyzed the influences of lightweight aggregate, water retention agent and thixotropic agent on compression strength, tensile bond strength, water retention rate and constructability of sprayable gypsum-based mortar. Based on this, the mixture ratio of sprayable gypsum-based mortar was determined and applied in practical engineering, which can obtain better economic benefits.

\section{Effects of mixture ratio of materials on performance of sprayable gypsum-based mortar}

Desulphurized gypsum. Phase composition greatly affects performance of gypsum and dihydrate gypsum can largely reduce setting time of gypsum and weaken retarding effects of retarder, so stable desulphurized gypsum with low content of dihydrate gypsum should be selected. In addition, too much unstable anhydrite in gypsum can increase water requirement of normal consistency, reduce strength and lead to unstable setting time of gypsum[5]. Therefore, calcined gypsum should be effectively aged to change extra soluble anhydrite into semi-hydrated gypsum, and it cannot be used to produce sprayable gypsum-based mortar before stabilizing physical property. The strength of 
desulphurized gypsum decides the strength of sprayable gypsum-based mortar and the strength of gypsum should be more than $6.0 \mathrm{MPa}$.

Lightweight aggregate. In order to decrease density of mortar, improve constructability and reduce wear of spraying equipment caused by mortar, lightweight aggregate was added into sprayable gypsum-based mortar to replace some fine sands. In engineering application, sprayable gypsum-based mortar with different contents of lightweight aggregate was used to carry out comparative experiment on equipment wear. The comprehensive loss costs of vulnerable parts of spraying equipment, such as a screw pump and a mixing shaft by using sprayable gypsum-based mortar containing .5\%, 3\% and $4.5 \%$ of lightweight aggregate were $0.4,0.28$ and $0.21 \mathrm{yuan} / \mathrm{m}^{2}$, respectively.

On the conditions that the amounts of desulphurized gypsum and cellulose ether were kept unchanged as $50 \%$ and $0.3 \%$ of the total, respectively, the amount of gypsum retarder was adjusted, so

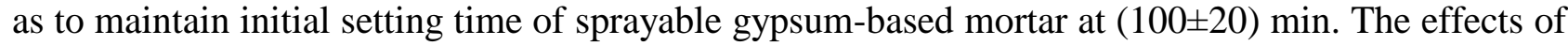
the content of lightweight aggregate on dry density and compression strength of sprayable gypsum-based mortar are shown in Table 1.

Table 1 Effects of the content of lightweight aggregate on dry density and compression strength of sprayable gypsum-based mortar

\begin{tabular}{|c|c|c|c|c|c|}
\hline $\begin{array}{c}\text { Content of lightweight } \\
\text { aggregate }(\%)\end{array}$ & 0 & 1.5 & 3.0 & 4.5 & 6.0 \\
\hline Dry density $\left(\mathrm{kg} / \mathrm{m}^{3}\right)$ & 1580 & 1280 & 1120 & 985 & 891 \\
\hline $\begin{array}{c}\text { Compression strength } \\
\text { (MPa) }\end{array}$ & 6.8 & 5.4 & 4.6 & 3.9 & 3.4 \\
\hline
\end{tabular}

As shown in Table 1, with the increase of the content of lightweight aggregate, the dry density and compression strength of sprayable gypsum-based mortar gradually decreased. When the content of lightweight aggregate was more than $4.5 \%$, the strength was lower than the standard requirement of 4.0 MPa. Sprayable gypsum-based mortar containing 3\% and $4.5 \%$ of lightweight aggregate had a low dry density and good constructability and was easily used in the construction[6]. Therefore, by comprehensively considering strength and constructability of gypsum-based mortar and loss costs of the equipment, the content of lightweight aggregate was primarily determined to be $3 \%$.

Additive. (1) Influences of the content of cellulose ether on performance of sprayable gypsum-based mortar.Cellulose ether, as a main additive for gypsum-based mortar, has the functions of holding water and thickening, raising cohesive force between mortar and walls and improving the construction.performance of mortar. Owing to stirring shaft of the spraying equipment for sprayable gypsum-based mortar is short, the mortar is generally stirred for 5-10 seconds. Therefore, cellulose ether with a rapid dissolution rate should be selected for sprayable gypsum-based mortar.

The contents of desulphurized gypsum and lightweight aggregate were kept as $50 \%$ and $3 \%$ of the total, while the content of gypsum retarder was adjusted, so that the initial setting time of

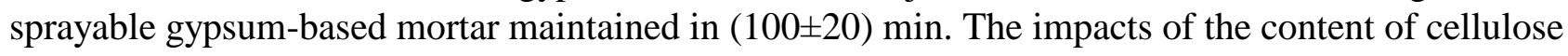
ether on water retention rate and tensile bond strength of sprayable gypsum-based mortar are demonstrated in Table 2.

Table 2 Impacts of the content of cellulose ether on water retention rate and tensile bond strength of sprayable gypsum-based mortar

\begin{tabular}{|l|c|c|c|c|c|c|}
\hline Content of cellulose ether (\%) & 0.05 & 0.10 & 0.15 & 0.20 & 0.25 & 0.30 \\
\hline Water retention rate (\%) & 62 & 65 & 73 & 90 & 93 & 95 \\
\hline $\begin{array}{l}\text { Tensile bond strength with concrete slabs } \\
\text { (MPa) }\end{array}$ & 0.23 & 0.36 & 0.44 & 0.46 & 0.45 & 0.45 \\
\hline $\begin{array}{l}\text { Tensile bond strength with aerated concrete } \\
\text { blocks (MPa) }\end{array}$ & 0.12 & 0.15 & 0.22 & 0.35 & 0.37 & 0.37 \\
\hline
\end{tabular}

Table 2 displays that with the rise of the content of cellulose ether, water retention rate of the sprayable gypsum-based mortar gradually raised. When the content of cellulose ether was $0.2 \%$, water retention rate of the mortar reached $90 \%$. Considering the actual conditions of use of sprayable gypsum-based mortar, the tensile bond strengths of the mortar with concrete slabs and aerated concrete blocks were tested. In terms of tensile bond strength with concrete slabs, when the content of 
cellulose ether was more than $0.15 \%$, tensile bond strength was high and changed slightly with the increase of the content of cellulose ether. To make the tensile bond strength with aerated concrete blocks could achieve the above effects, the content of cellulose ether needed to exceed $0.2 \%$ due to the influence of high water absorption of aerated concrete blocks[7]. Considering that with the increase of the content of cellulose ether, the water consumption of mortar rose, while rapture strength and compression strength decreased, so the content of cellulose ether was $0.2 \%$.

(2)Effects of the content of starch ether on performance of sprayable gypsum-based mortar.Adding starch ether into sprayable gypsum-based mortar can improve sagging resistance and lubricity of the mortar and improve the operational performances, so as to operate smoothly and meet construction requirements. Differing from traditional plastering construction which generally adopts the layered construction method, the mechanical spraying construction only needs to spray one layer. This put forward high requirements for wet adhesion and thixotropy of sprayable gypsum-based mortar. By simulating spraying test through adding different contents of starch ether, it was obtained that adding $0.03-0.07 \%$ of starch ether in the mixture endowed the mortar with good sagging resistance and lubricity, thus meeting construction requirements.

(3)Retarder .Sprayable gypsum-based mortar is generally operated for 1.0-1.5 h, while the setting time of desulphurized gypsum is short, generally ranging from a few minutes to a dozen minutes, so it cannot meet the requirements on construction time. Therefore, retarder has to be added into gypsum cementitious material so as to meet the requirements for normal construction. The mechanism of action of retarder is shown as follows: it reduces solubility and dissolution rate of semi-hydrated gypsum. Polar molecules of retarder are adsorbed on the surface of growing dihydrate gypsum crystal and are combined into lattice, thus generating strong adsorption and inhibiting the growth of dihydrate gypsum embryos[8]. Moreover, complexes are formed which limit the diffusion of ions to the vicinity of dihydrate gypsum crystal. The generally used gypsum retarders include organic acid and its soluble salts, such as tartaric acid, citric acid and citrate, and phosphate. However, the utilization of retarder can cause serious loss of strength of gypsum products, so composite retarder that can meet the requirement for retarding and reduce the loss of strength of hardened gypsum as much as possible should be selected.

\section{Formula determination and performance test of sprayable gypsum-based mortar}

Based on a large number of tests and researches, the formula for producing sprayable gypsum-based mortar was finally determined, as shown in Table 3 and the performance test results are displayed in Table 4. It can be seen that compression strength and tensile bond strength are larger than 4.0 $\mathrm{MPa}$ and $0.3 \mathrm{MPa}$, respectively.

Table 3 Formula for producing sprayable gypsum-based mortar

\begin{tabular}{|c|c|c|c|c|c|}
\hline $\begin{array}{c}\text { Desulphurized } \\
\text { gypsum }\end{array}$ & $\begin{array}{c}\text { Lightweight } \\
\text { aggregate }\end{array}$ & Fine sand & $\begin{array}{c}\text { Water } \\
\text { retention } \\
\text { agent }\end{array}$ & $\begin{array}{c}\text { Gypsum } \\
\text { retarder }\end{array}$ & $\begin{array}{c}\text { Thixotropic } \\
\text { agent }\end{array}$ \\
\hline 50 & 3 & 46.6 & 0.2 & 0.25 & 0.05 \\
\hline
\end{tabular}

Table 4 Performance test results of gypsum-based mortar produced using the determined formula

\begin{tabular}{|c|c|c|c|c|c|c|}
\hline $\begin{array}{c}\text { Initial } \\
\text { setting } \\
\text { time } \\
(\mathrm{min})\end{array}$ & $\begin{array}{c}\text { Final } \\
\text { setting } \\
\text { time } \\
(\mathrm{min})\end{array}$ & $\begin{array}{c}\text { Water } \\
\text { retention } \\
\text { rate } \\
(\%)\end{array}$ & $\begin{array}{c}\text { Rupture } \\
\text { strength } \\
(\mathrm{MPa})\end{array}$ & $\begin{array}{c}\text { Compre } \\
\text { ssion } \\
\text { strength } \\
(\mathrm{MPa})\end{array}$ & $\begin{array}{c}\text { Tensile bond } \\
\text { strength with } \\
\text { concrete slabs } \\
(\mathrm{MPa})\end{array}$ & $\begin{array}{l}\text { Tensile bond strength } \\
\text { with aerated concrete } \\
\text { block }\end{array}$ \\
\hline 85 & 104 & 89 & 2.3 & 4.7 & 0.45 & 0.37 \\
\hline
\end{tabular}




\section{Conclusion}

(1)Adding 3\% of lightweight aggregate into the sprayable gypsum-based mortar decreased the density of mortar, improved constructability and reduced the wear of spraying equipment. When the content of cellulose ether was $0.2 \%$, sprayable gypsum-based mortar showed high water retention rate and tensile bond strength. Adding $0.03-0.07 \%$ of starch ether in the mixture ratio enhanced sagging resistance and lubricity and improved operational performance to operate smoothly, thus meeting construction requirements.

(2)The performance of the sprayable gypsum-based mortar prepared with the mixture ratio determined through the test meets the standard requirements.

(3)The sprayable gypsum-based mortar has simple construction process and good effects. Furthermore, a large number of waste residues of desulphurized gypsum are recycled. Therefore, it has broad market prospects.

\section{References}

[1] Qian Yaoli and Ye Beihong. Preparation and performance of water-resistant gypsum mortar. Low Temperature Architecture Technology, 2014 (10),p. 16-18

[2] Zhu Jiang, Li Guozhong and Wang Yingzi. Preparation and research of desulphurization gypsum / fly ash plastering material. Block-Brick Tile.2012(8), p. 44-47.

[3] Wang Lanying, Zhu Weizhong, Dou Zhengping et al. Comprehensive utilization of resources of desulphurized gypsum in gypsum plaster for inner walls. Block-Brick Tile. 2017(1), p. 28-29.

[4] Cobble. Advanced ceramic paste layer technology and ceramic tile adhesive. New Building Materials, 1999, No.2(1999),P.17 19 (in Chinese)

[5] Changsheng Zhou. The performance and applications of a new polymer-modified cement-based composite. Building Technology Development, No.12(2000),p.33

[6] Houli Xie. Study on the Compounding and Performance of New Type binding Mortar. Master thesis, Chongqing University, 2001,p.22 32

[7] Jiliang Chen. Applications of Dispersible polymer powders in the building exterior insulation and anti-carck.. Architectural Design Management, Vol.11(2009), p.79-80

[8] Baoguo Ma, Yuanyuan Wu etc. Impact of Interfacial Adhesion on Polymermodified Cement Mortar. Materials Review, vol.23(2009),P.63-64 